\title{
KAJIAN KARAKTERISASI TUTUPAN LAHAN KAWASAN PENYANGGA SITU BOJONGSARI DAN SIMULASI OPTIMASI INFILTRASI UNTUK MENGURANGI RISIKO BANJIR
}

\author{
Akhmadi Puguh Raharjo ${ }^{1}$
}

\begin{abstract}
ABSTRAK: Situ di kawasan perkotaan memiliki fungsi penting dalam mengurangi dampak banjir dan menyediakan sumber air bersih di kawasan perkotaan. Laju pertumbuhan kawasan perkotaan mengancam keberlangsungan situ, khususnya di kawasan Jakarta dan sekitarnya. Tujuan dari studi ini adalah untuk mengkarakterisasi tutupan lahan pada kawasan penyangga Situ Bojongsari dan melakukan simulasi optimasi tutupan lahan menggunakan biopori untuk mengurangi risiko banjir. Data tutupan lahan didapatkan menggunakan aplikasi daring berbasis web (i-Tree Canopy) dengan enam tipe tutupan lahan yang berbeda. Estimasi tutupan lahan untuk kelas terbangun (atap dan jalan) dan untuk kelas alami (pohon, rumput atau tumbuhan bawah, badan air dan lahan terbuka) mencapai 34,70 \pm 1,51\% dan 65,30 \pm 1,51\% berturut-turut dari total 757,64 hektar luas wilayah studi. Aplikasi biopori diharapkan mampu mengurangi debit puncak sebesar 12\%. Kombinasi dengan pendekatan bioteknologi lainnya diperlukan untuk lebih menurunkan debit puncak di masa yang akan datang.
\end{abstract}

Kata kunci: situ perkotaan, mitigasi banjir, bioteknologi.

ABSTRACT: Urban lakes has an important function in reducing the impact of flooding and provide a source of clean water in urban areas. The rate of urban development threatens the sustainability of urban lakes, especially in Greater Jakarta. The purpose of this study was to characterize land cover in the buffer zone of Situ Bojongsari and perform infiltration optimization simulations using biopori to reduce the risk of flooding. Land cover data were obtained using a web based application (i-Tree Canopy) with six different land cover types. Specific land cover classes targeted for this particular application is tree cover, grass/ undergrowth and open land. Estimation of land cover for developed area classes (roof and roads) and for natural area classes (trees, grass/undergrowth, water surface and open area) are amounted to approximately $34.70 \pm 1.51 \%$ and $65.30 \pm 1.51 \%$ respectively from the total 757,64 hectares of total land areas. Application of biopori is expected to reduce peak discharge of $12 \%$. Combination with other biotechnological approaches is needed to further decrease peak flows in the future.

Keywords: urban lakes, flood mitigation, biotechnology.

1. PTRRB - TPSA - BPPT, JI. M. H. Thamrin No. 8, Jakarta 10340.

email:puguh_x@yahoo.com 


\section{PENDAHULUAN}

\subsection{Latar Belakang}

Pengertian Situ menurut Inmendagri No. 14 Tahun 1998 mengenai Pembinaan Pengelolaan Situ-situ di Wilayah Jabotabek adalah suatu wadah atau genangan air di atas permukaan tanah yang terbentuk secara alami maupun buatan yang airnya berasal dari air tanah atau air permukaan sebagai siklus hidrologis yang potensial dan merupakan salah satu kawasan lindung.

Dari berbagai fungsi situ yang beragam secara ekologis dan hidrologis (Alikodra, 1998), peran situ yang paling utama di kawasan perkotaan, khususnya di kawasan Jabodetabek, adalah untuk mengurangi dampak banjir kiriman dari dataran tinggi dan untuk membantu mengatasi masalah krisis air di daerah hilir. Selain itu, situ dapat juga dikelola sebagai sarana rekreasi, pendidikan maupun sebagai sarana peningkatan ekonomi.

Bila dibandingkan dengan kebanyakan danau alami, situ pada umumnya berukuran kecil dan dangkal dengan daerah aliran sungai yang besar dan ditandai dengan tutupan tidak tembus air, seperti perkerasan, jalan dan bangunan yang cukup substansial. Kondisi ini juga masih ditambah dengan kurangnya tutupan vegetasi yang berpengaruh negatif terhadap kesehatan situ. Penyusutan danau, polusi, dan eutrofikasi merupakan masalah yang umum dihadapi oleh situ-situ di kawasan perkotaan (Henny dan Meutia, 2014).

Lebih lanjut Henny dan Meutia (2014) membagi situ-situ di kawasan perkotaan menjadi 8 kelas yang berbeda berdasarkan tipe kawasan yang melingkupinya (Tabel 1). Situ Bojongsari, yang menjadi objek kajian dalam penelitian ini, menurut klasifikasi tersebut masuk ke dalam kategori $D$, yakni situ yang berada di sekitar kawasan perkampungan di kawasan pedesaan. Sementara itu pada Tabel 2 disajikan tipe ancaman terhadap situ dan tingkat risiko untuk ancaman itu bisa terjadi. Untuk situ pada kategori D seperti Situ Bojongsari, tingkat risiko untuk terjadinya penyusutan situ, sedimentasi dan eutrofikasi adalah tinggi, sementara risiko untuk terjadinya polusi situ adalah menengah sampai tinggi.

Melihat kedudukan situ-situ di kawasan Jabodetabek yang memiliki fungsi amat penting dalam membantu mengurangi risiko banjir kiriman dari hulu, perlu adanya upaya untuk mengatasi hal-hal yang mengancam kelestarian situ. Perlu dilakukan suatu kajian mendetail terhadap kondisi kawasan penyangga situ tersebut dan mengkaji langkah-langkah yang bisa dilakukan untuk dapat menyelamatkan situsitu tersebut dari kerusakan di masa depan.

\subsection{Tujuan}

Tujuan dari penelitian ini adalah melakukan karakterisasi tutupan lahan di kawasan penyangga Situ Bojongsari menggunakan aplikasi dari i-Tree Canopy. Tujuan lainnya adalah untuk melakukan simulasi optimasi tutupan lahan menggunakan lubang resapan biopori (LRB) pada kondisi debit rencana untuk mengurangi risiko banjir.

Tabel 1. Klasifikasi situ berdasarkan tipe kawasan di sekitarnya.

\begin{tabular}{|c|c|}
\hline $\begin{array}{l}\text { Tipe Kawasan } \\
\text { Sekitar Situ }\end{array}$ & Karakteristik \\
\hline $\begin{array}{l}\text { A. Kawasan Urban } \\
\text { Village }\end{array}$ & $\begin{array}{l}\text { Perumahan tidak teratur dan } \\
\text { padat, lebar jalan tidak memadai }\end{array}$ \\
\hline $\begin{array}{l}\text { B. Kawasan } \\
\text { Pemukiman Teratur }\end{array}$ & $\begin{array}{l}\text { Perumahan teratur, lebar jalan } \\
\text { memadai }\end{array}$ \\
\hline $\begin{array}{l}\text { C. Kawasan } \\
\text { Pemukiman } \\
\text { Bertingkat }\end{array}$ & $\begin{array}{l}\text { Bangunan tinggi, umumnya } \\
\text { perkantoran dan apartemen }\end{array}$ \\
\hline $\begin{array}{l}\text { D. Kawasan Rullar } \\
\text { Village }\end{array}$ & $\begin{array}{l}\text { Perumahan tidak terlalu padat } \\
\text { bercampur dengan area } \\
\text { pertanian }\end{array}$ \\
\hline $\begin{array}{l}\text { E. Kawasan Rullar - } \\
\text { Urban Village }\end{array}$ & $\begin{array}{l}\text { Pertemuan antara kawasan } \\
\text { perkotaan dan pedesaan }\end{array}$ \\
\hline F. Kawasan Industri & $\begin{array}{l}\text { Didominasi oleh bangunan } \\
\text { pabrik }\end{array}$ \\
\hline $\begin{array}{l}\text { G. Kawasan Industri } \\
\text { - Urban Village }\end{array}$ & $\begin{array}{l}\text { Percampuran antara kawasan } \\
\text { industri dan pemukiman }\end{array}$ \\
\hline $\begin{array}{l}\text { H. Kawasan } \\
\text { Peratnian }\end{array}$ & $\begin{array}{l}\text { Lebih dari } 50 \% \text { kawasan } \\
\text { sekitarnya terdiri atas pertanian }\end{array}$ \\
\hline
\end{tabular}

Sumber: Henny dan Meutia (2014). 
Tabel 2. Beberapa tipe kondisi yang menjadi ancaman bagi situ dan level risikonya.

\begin{tabular}{|c|c|c|c|c|}
\hline \multirow{2}{*}{$\begin{array}{l}\text { Tipe Penggunaan } \\
\text { Lahan Sekitar Situ }\end{array}$} & \multicolumn{4}{|c|}{ Tipe Kondisi dan Level Risiko } \\
\hline & Penyusutan Situ & Sedimentasi & Eutrofikasi & Polusi Situ \\
\hline$A$ & Tinggi & Tinggi & Tinggi & Tinggi \\
\hline B & Rendah & Menengah & Rendah - Menengah & Rendah - Menengah \\
\hline $\mathrm{C}$ & Rendah & Menengah & Rendah - Menengah & Rendah - Menengah \\
\hline $\mathrm{D}$ & Tinggi & Tinggi & Tinggi & Menengah - Tinggi \\
\hline$E$ & Tinggi & Tinggi & Tinggi & Tinggi \\
\hline $\mathrm{F}$ & Menengah & Menengah & Menengah - Tinggi & Tinggi \\
\hline G & Tinggi & Tinggi & Tinggi & Tinggi \\
\hline $\mathrm{H}$ & Tinggi & Tinggi & Tinggi & Menengah - Tinggi \\
\hline
\end{tabular}

Sumber: Henny dan Meutia (2014).

\section{METODOLOGI}

\subsection{Tempat Dan Waktu Penelitian}

Penelitian ini dilaksanakan di Sub Daerah Aliran Sungai (DAS) yang melingkupi Situ Bojongsari (luas 757.64 hektar) dan terletak di Kotamadya Depok. Situ ini merupakan situ terluas di Kota Depok dan masuk ke dalam DAS Angke.

Penelitian ini dilaksanakan sejak pertengahan tahun 2016 yakni melalui studi pustaka dan kajian awal, yang diikuti dengan pengambilan data lapangan awal pada bulan Juni dan pengambilan data lanjutan pada bulan Oktober.

\subsection{Sampling Dan Analisis Sampel}

Data yang dibutuhkan dalam penelitian ini didapatkan baik secara primer maupun sekunder. Data primer diantaranya adalah data tutupan lahan di Sub DAS Bojongsari, data jenis tanaman pada beberapa zona permukiman dan data-data terkait penggunaan lahan. Sementara untuk data sekunder diantaranya adalah data-data pendukung terkait Situ Bojongsari, kondisi curah hujan Kota Depok, pustaka mengenai intersepsi hujan dan lain sebagainya.

\section{Data Tutupan Lahan}

Data tutupan lahan di lokasi penelitian didapatkan menggunakan aplikasi daring $i$-Tree Canopy (http://canopy.itreetools.org/index. php). i-Tree Canopy sendiri adalah aplikasi daring yang dirancang untuk mempermudah pengguna dalam mengestimasi tutupan pepohonan maupun kelas tutupan lahan lainnya dalam wilayah kota dimana mereka tinggal, maupun lokasi lain yang dikehendaki, dengan mudah dan akurat.

Prinsip kerja aplikasi ini adalah peletakan sejumlah titik secara acak, sesuai jumlah yang diinginkan oleh pengguna, ke atas citra Google Earth. Lalu dengan menggunakan kelas tutupan lahan yang telah ditetapkan sebelumnya, pengguna dapat memilih kelas tutupan lahan yang tepat dari menu dropdown sesuai gambaran pada citra Google Earth. Estimasi persentase tutupan lahan kemudian dapat disajikan ke dalam format PDF.

Citra Google Earth yang digunakan adalah citra terbaru hasil akuisisi pada tanggal 23 Agustus 2016. Mekanisme pengambilan data tutupan lahan lokasi penelitian adalah sebagai berikut:

- Melakukan pembatasan Sub DAS yang akan didentifikasi menggunakan peta DAS yang diperoleh dari DEM (Digital Elevation Model) terbaru,

- Melakukan pembagian wilayah berdasarkan tiga penggunaan lahan dasar seperti badan air (termasuk di dalamnya kolam dan sawah), permukiman (termasuk di dalamnya 
kawasan komersial, pendidikan dan industri) dan ruang terbuka hijau (termasuk di dalamnya padang golf, kebun, dan tanah kosong, baik dengan tutupan rumput maupun tidak).

- Kawasan permukiman dibedakan lebih lanjut atas dasar keteraturan, yakni permukiman teratur dan permukiman tidak teratur.

- Melakukan identifikasi tutupan lahan menggunakan aplikasi i-Tree Canopy berdasarkan kenampakan tutupan dengan enam kelas tutupan lahan yang telah ditetapkan yakni badan air, tutupan pohon, tutupan rumput/ tumbuhan penutup tanah, bangunan, jalan/perkerasan dan terbuka.

Hasil estimasi tersebut kemudian dapat disajikan sebagai tabel untuk dibahas lebih lanjut. Proses klasifikasi tutupan lahan menggunakan i-Tree Canopy bisa dilihat secara online.

\section{Data Curah Hujan}

Data curah hujan penting kedudukannya untuk mendapatkan nilai intensitas curah hujan, waktu konsentrasi dan debit banjir rancangan. Data-data tersebut penting untuk melihat sebesar apa debit banjir yang mengancam kawasan yang menjadi lokasi penelitian dan apakah aplikasi biopori mampu memitigasi ancaman tersebut. Intensitas hujan ( $\mathrm{mm} / \mathrm{jam})$ dapat didapatkan dari data hujan harian $(\mathrm{mm})$ secara empitik menggunakan metode Mononobe sebagai berikut:

$$
I=\frac{R_{24}}{24}\left(\frac{24}{t}\right)^{2 / 3}
$$

dimana:

$$
\begin{aligned}
I= & \text { intensitas curah hujan ( } \mathrm{mm} / \mathrm{jam}) ; \\
t= & \text { lamanya curah hujan (jam); dan } \\
R_{24}= & \text { curah hujan maksimum dalam } 24 \\
& \text { jam (mm) }
\end{aligned}
$$

Sementara itu waktu konsentrasi dapat didapatkan menggunakan formula dari Kirpich sebagai berikut:

$$
\begin{aligned}
t_{c}=0,06628 L^{0,77} S^{-0,385} \\
\text { dimana: } \\
t_{c}=\text { waktu konsentrasi (jam); } \\
L=\text { panjang saluran dari hulu } \\
\text { sampai titik kontrol ( } \mathrm{km}) ; \text { dan } \\
S=\begin{array}{l}
\text { kemiringan rata-rata saluran } \\
(\mathrm{m} / \mathrm{m})
\end{array}
\end{aligned}
$$

Debit rancangan kemudian dapat dihitung menggunakan rumus metode Rasional sebagai berikut:

dimana:

$$
Q_{T}=0,00278 C I_{t c, T} A
$$

$$
\begin{aligned}
Q_{T}= & \text { debit puncak ( } \mathrm{m}^{3} / \text { detik) untuk } \\
& \text { periode ulang T tahun; } \\
C= & \text { koefisien aliran permukaan (run } \\
& \text { off), yang dipengaruhi kondisi } \\
& \text { tata guna lahan pada daerah } \\
& \text { tangkapan air (DAS); } \\
I_{t c, T}= & \text { intensitas hujan rata-rata } \\
& \text { (mm/jam) untuk waktu } \\
& \text { konsentrasi (tc) dan kala ulang } \\
& \text { T tahun; dan aran tangkapan air/DAS } \\
A= & \text { luas daerah tang } \\
& \text { (Hektar / Ha). }
\end{aligned}
$$

Data hujan yang digunakan dalam penelitian ini adalah data hujan harian maksimum selama kurun waktu 2006-2010 di Stasiun Depok. Data tersebut, bersama data hasil analisis intensitas hujan, didapatkan dari sumber literatur (Sriyono, 2012).

\section{Simulasi Optimasi}

Dari data debit rancangan yang didapatkan, bisa dilakukan simulasi aplikasi biopori pada kelas tutupan lahan tertentu seperti kelas tutupan pohon, kelas tutupan rumput/ tumbuhan bawah dan kelas lahan terbuka. Jumlah biopori yang dibutuhkan bisa didapatkan dengan membagi debit puncak dengan kapasitas peresapan biopori. Jarak antara biopori dapat didapatkan dengan membagi luas wilayah dengan jumlah biopori yang dibutuhkan (Juliastuti 
dan Suhendra, 2011).

Dari data tersebut di atas bisa dilakukan analisis perubahan debit puncak dari kondisi sebelum dan sesudah dilakukan simulasi aplikasi biopori pada kelas tutupan lahan yang bersangkutan maupun dari lokasi penelitian secara keseluruhan.

\section{HASIL DAN PEMBAHASAN}

\subsection{Estimasi Tutupan Lahan}

Hasil estimasi tutupan lahan untuk tipe penggunaan lahan permukiman menunjukkan beberapa perbedaan mendasar di antara tipe permukiman teratur dan permukiman tidak teratur. Perbedaan paling mendasar di antara dua tipe perumahan ini terletak pada alokasi besaran persentase lahan terbangun (bangunan, jalan dan perkerasan) dan lahan alami (tutupan pohon, rumput, lahan kosong dan badan air). Perumahan teratur hampir secara umum menunjukkan persentase areal terbangun yang lebih rendah bila dibandingkan dengan persentase areal alaminya. Hasil yang berlawanan ditunjukkan oleh perumahan tidak teratur dimana areal terbangunnya lebih tinggi bila dibandingkan dengan areal alaminya (Tabel 3). Luas kawasan permukiman adalah sebesar 385,48 hektar.
Perbedaan lainnya adalah tutupan bangunan di perumahan tidak teratur yang tercatat lebih tinggi bila dibandingkan dengan tipe tutupan yang sama pada perumahan teratur $(46,54 \pm 1,59 \%$ vs $25,55 \pm 1,38 \%$ ), namun dengan tutupan jalan/ perkerasan yang lebih tinggi bila dibandingkan dengan perumahan tidak teratur $(23,55 \pm 1.38$ vs $17.11 \pm 1.20)$. Hal ini bisa kita saksikan sendiri dari jalan-jalan di perumahan teratur yang umumnya lebih lebar bila dibandingkan dengan jalan-jalan pada perumahan tidak teratur.

Dari segi perbandingan ukuran rumah, perumahan teratur memiliki ukuran rumah yang lebih kecil (relatif terhadap ukuran halamannya) bila dibandingkan dengan ukuran rumah pada perumahan tidak teratur. Tutupan pepohonan dan rumput ataupun tanaman penutup tanah tercatat lebih tinggi pada perumahan teratur. Hal ini bisa dikatakan wajar bila mengingat bahwa perumahan teratur umumnya memiliki jalur hijau pepohonan di antara median jalannya serta halaman yang umumnya ditutupi oleh rumput.

Hasil estimasi persentase tutupan lahan pada penggunaan permukiman juga menunjukkan adanya pola yang tumpang tindih antara permukiman yang memiliki pola teratur dan yang memiliki pola tidak teratur.

Hal ini bisa dilihat dari pola perbandingan kelas tutupan lahan yang mewakili kelas terbangun

Tabel 3. Hasil estimasi tutupan lahan pada penggunaan lahan permukiman berdasarkan tipe keteraturan dan dominansi jenis tutupan yang dominan.

\begin{tabular}{|c|c|c|c|c|c|}
\hline \multirow{2}{*}{$\begin{array}{c}\text { Klasifikasi Kelas Tutupan } \\
\text { Lahan }\end{array}$} & \multicolumn{5}{|c|}{ Estimasi Tutupan Lahan (\%) } \\
\hline & $\begin{array}{l}\text { Pemukiman } \\
\text { Teratur }\end{array}$ & $\begin{array}{l}\text { Pemukiman } \\
\text { Tidak Teratur }\end{array}$ & $\begin{array}{l}\text { Dominan } \\
\text { Terbangun }\end{array}$ & Dominan Alami & Total \\
\hline Terbangun & $49.53 \pm 1.62$ & $63.65 \pm 1.53$ & $59.85 \pm 0.94$ & $40.24 \pm 1.43$ & $34.70 \pm 1.51$ \\
\hline Bangunan & $25.97 \pm 1.42$ & $46.54 \pm 1.59$ & $40.55 \pm 0.94$ & $25.27 \pm 1.26$ & $23.30 \pm 1.34$ \\
\hline Perkerasan/ Jalan & $23.55 \pm 1.38$ & $17.11 \pm 1.20$ & $19.30 \pm 0.76$ & $14.96 \pm 1.04$ & $11.40 \pm 1.01$ \\
\hline Alami & $50.47 \pm 1.48$ & $36.35 \pm 1.53$ & $40.15 \pm 0.94$ & $59.76 \pm 1.43$ & $65.30 \pm 1.51$ \\
\hline Pohon & $29.86 \pm 1.48$ & $24.13 \pm 1.37$ & $26.46 \pm 0.85$ & $35.08 \pm 1.39$ & $24.30 \pm 1.36$ \\
\hline Rumput/ Tumbuhan bawah & $16.82 \pm 1.21$ & $8.25 \pm 1.88$ & $9.47 \pm 0.56$ & $19.95 \pm 1.16$ & $26.90 \pm 1.40$ \\
\hline Air/ Kolam/ Sawah & $1.05 \pm 0.33$ & $1.43 \pm 0.38$ & $1.54 \pm 0.24$ & $1.61 \pm 0.37$ & $6.80 \pm 0.80$ \\
\hline Terbuka & $2.73 \pm 0.53$ & $2.55 \pm 0.50$ & $2.68 \pm 0.31$ & $2.13 \pm 0.51$ & $7.30 \pm 0.82$ \\
\hline Potensi Aplikasi Bioteknologi & $49.42 \pm 1.62$ & $34.93 \pm 1.52$ & $38.61 \pm 0.93$ & $58.16 \pm 1.43$ & $58.50 \pm 1.56$ \\
\hline Terbuka + Rumput & $19.56 \pm 1.29$ & $10.79 \pm 0.99$ & $12.15 \pm 0.63$ & $23.08 \pm 1.22$ & $34.20 \pm 1.56$ \\
\hline Pohon & $29.86 \pm 1.48$ & $24.13 \pm 1.37$ & $26.46 \pm 0.85$ & $35.08 \pm 1.39$ & $24.30 \pm 1.36$ \\
\hline
\end{tabular}

Sumber: Pengolahan hasil $i-T r e e$ Canopy. 
dan kelas tutupan lahan yang mewakili tutupan alamiah. Ada perumahan teratur yang memiliki persentase tutupan terbangun yang lebih besar bila dibandingkan dengan persentase tutupan alamiahnya. Sebaliknya, ada pula perumahan tidak teratur yang memiliki persentase tutupan alamiah yang lebih besar bila dibandingkan dengan persentase tutupan terbangunnya.

Disebabkan adanya hal tersebut di atas, maka dilakukanlah pengelompokan lebih lanjut berdasarkan dominansi kelas tutupan lahannya, baik terbangun maupun alamiah (Tabel 3). Hasil dari pengelompokan tersebut disajikan dalam Gambar 1. hektar), persentase tutupan lahan terbesar ditempati oleh tutupan pepohonan $(34,20$ $\pm 2,12 \%$ ) yang diikuti oleh tutupan rumput/ tumbuhan bawah $(33,00 \pm 2,10 \%)$. Kondisi tutupan alamiahnya masih di atas $90 \%$, yang menunjukkan kondisi yang masih bisa dibilang amat baik. Tutupan terbangun di kelas ini penggunaan lahan diantaranya sebagai jalan dan sebagian kecil sebagai bangunan. Hasil selengkapnya bisa dilihat pada Tabel 4 .

Untuk kelas tutupan lahan yang mewakili Situ Bojongsari, persentase tutupan lahan terbesar ditempati oleh badan air situ itu sendiri $(48,56 \pm 2,45 \%)$ yang diikuti oleh

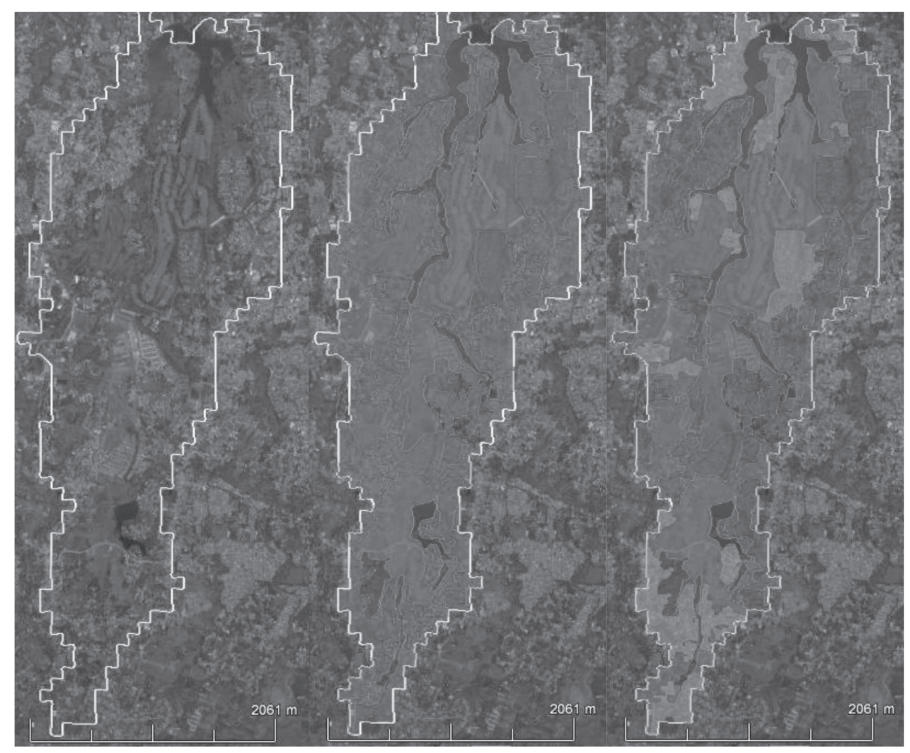

Gambar 1. Batasan Sub DAS yang menjadi lokasi penelitian (kiri); Pembagian sub DAS menjadi tiga kelas tutupan lahan, dimana warna merah mewakili tutupan bangunan, warna hijau mewakili tutupan vegetasi dan warna biru mewakili tutupan badan air (tengah); dan pembagian lebih lanjut kelas tutupan lahan bangunan menjadi tiga, dimana warna merah mewakili tutupan bangunan yang didominasi oleh lahan terbangun, warna jingga mewakili tutupan bangunan yang didominasi oleh lahan alami dan warna merah muda mewakili kondisi perumahan yang sedang dalam tahap pembangunan (kanan). (Sumber: Pengolahan citra Google Earth).

Untuk kelas tutupan lahan yang mewakili ruang terbuka hijau (luas total 64,01 tutupan kolam/sawah $(20,19 \pm 1,97 \%)$. Kondisi tutupan alamiahnya masih di atas $95 \%$, yang 
menunjukkan kondisi yang amat baik. Hanya saja, sebagian besar wilayah situ di sebelah selatan dan barat daya situ sudah mengalami pendangkalan dan eutrofikasi yang parah. Terdapat areal yang cukup luas (11,54 $\pm 1,57 \%)$ yang merupakan badan situ yang telah men jadi daratan dan ditumbuhi oleh rumput liar. Terdapat pula alih fungsi penggunaan lahan situ menjadi kolam ataupun sawah di sebelah selatan Situ Bojongsari (Gambar 2). Tutupan terbangun di Situ Bojongsari diantaranya sebagai jalan $(1,20 \pm 0,537 \%)$ dan sebagian kecil sebagai bangunan $(0,48 \pm 0,34 \%)$. Hasil selengkapnya bisa dilihat pada Tabel 4.

Tabel 4. Hasil estimasi tutupan lahan pada penggunaan lahan ruang terbuka hijau danpada Situ Bojongsari.

\begin{tabular}{lrr}
\hline \multirow{2}{*}{$\begin{array}{c}\text { Klasifikasi Kelas Tutupan } \\
\text { Lahan }\end{array}$} & \multicolumn{2}{c}{$\begin{array}{c}\text { Estimasi } \\
\text { (\%) }\end{array}$} \\
\cline { 2 - 3 } & \multicolumn{1}{c}{ RTH } & \multicolumn{1}{c}{$\begin{array}{c}\text { Situ } \\
\text { Bojongsari }\end{array}$} \\
\hline Terbangun & $\mathbf{9 . 7 3} \pm \mathbf{1 . 4 1}$ & $\mathbf{1 . 6 8} \pm \mathbf{0 . 6 3}$ \\
Bangunan & $3.60 \pm 0.83$ & $0.48 \pm 0.34$ \\
Perkerasan/ Jalan & $5.00 \pm 0.97$ & $1.20 \pm 0.53$ \\
Alami & $\mathbf{9 1 . 4 0 \pm 1 . 2 5}$ & $\mathbf{9 8 . 3 2} \pm \mathbf{0 . 6 3}$ \\
Pohon & $34.20 \pm 2.12$ & $8.89 \pm 1.40$ \\
Rumput/ Tumbuhan bawah & $33.00 \pm 2.10$ & $11.54 \pm 1.57$ \\
Kolam & $5.60 \pm 1.03$ & $20.19 \pm 1.97$ \\
Ladang & $11.60 \pm 1.43$ & $6.97 \pm 1.25$ \\
Terbuka & $7.00 \pm 1.14$ & $2.16 \pm 0.71$ \\
Situ & \multicolumn{2}{|c|}{$48.56 \pm 2.45$} \\
\hline Potensi Aplikasi & $\mathbf{8 5 . 8 0} \pm \mathbf{1 . 5 6}$ & \\
\hline Terbuka + Rumput & $45.25 \pm 2.37$ & \\
Pohon & $34.20 \pm 2.12$ & \\
Ladang & $11.60 \pm 1.43$ & \\
\hline Sumber & &
\end{tabular}

Sumber: Pengolahan hasil i-Tree Canopy.

Apabila dilihat dari segi luasannya, Situ Bojongsari memiliki luas perairan sebesar kurang lebih 20 hektar (dari seluas 41 hektar areal alaminya). Hal ini berarti telah terjadi pengurangan luasan situ sebesar $50 \%$ dari luasan alaminya. Luasan areal yang sudah menjadi daratan dan saat ini ditutupi rumput tercatat lebih kurang sebesar 4,8 hektar dan luasan kolam di sebelah selatannya lebih kurang sebesar 8 hektar. Areal terbangun di bantaran Situ Bojongsari didominasi rumah makan dan jalan kecil.

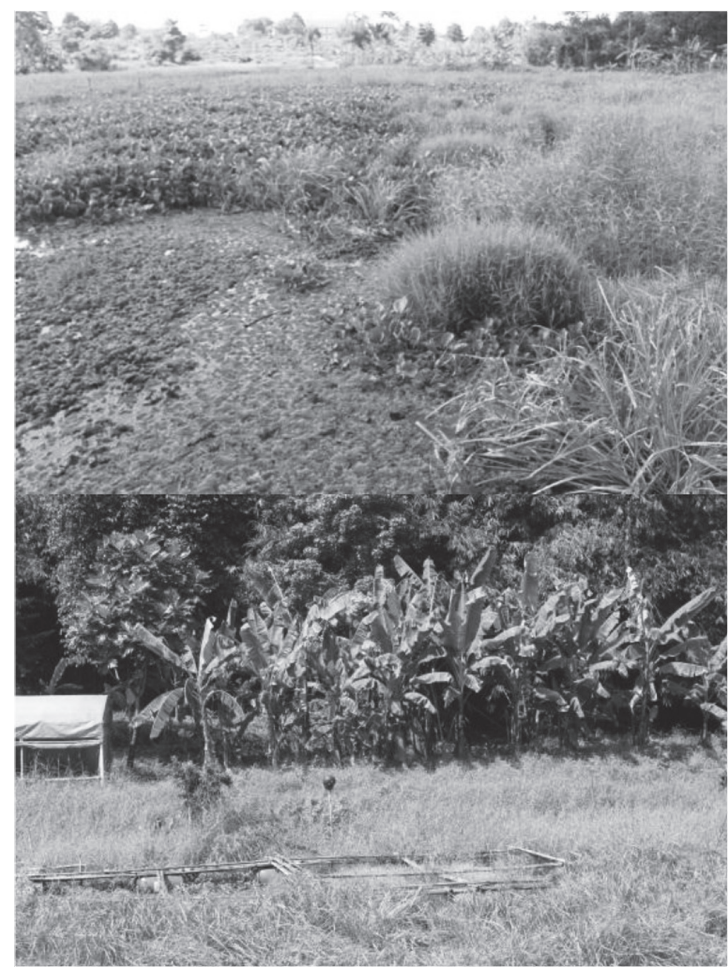

Gambar 2. Kondisi Situ Bojongsari yang mengalami pendangkalan dan alih fungsi lahan.

\subsection{Estimasi Debit Rancangan}

Dengan parameter panjang saluran (L) sepanjang $5,94 \mathrm{~km}$ dan kemiringan saluran sebesar 0,005 maka diperoleh waktu konsentrasi (Tc) sebesar 2,01 jam atau dibulatkan menjadi 120 menit. Dari Tabel 5 di atas bisa dilihat intensitas hujan pada waktu konsentrasi tersebut dan pada periode ulangan tertentu.

Dari data tersebut kemudian bisa dihitung debit untuk kelas tutupan yang menjadi target simulasi yakni tutupan pohon, rumput dan tanah terbuka. Hasil debit yang didapatkan kemudian dibagi oleh kapasitas peresapan biopori yang didapatkan dari studi literatur (Juliastuti dan Suhendra, 2011) yang 
Tabel 5. Hasil analis intensitas hujan kawasan sekitar Situ Bojongsari.

\begin{tabular}{|c|c|c|c|c|c|c|c|c|}
\hline \multirow{2}{*}{\multicolumn{2}{|c|}{$\mathbf{T}$}} & \multicolumn{7}{|c|}{ Intesitas Hujan Rata-rata (mm/ jam) } \\
\hline & & \multicolumn{7}{|c|}{ Periode Ulang (Tahun) } \\
\hline Menit & Jam & 2 & 5 & 10 & 25 & 50 & 100 & 1000 \\
\hline 5 & 0.08 & 175.53 & 201.29 & 214.75 & 229.10 & 238.37 & 46.72 & 270.09 \\
\hline 10 & 0.17 & 110.58 & 126.80 & 135.28 & 144.32 & 150.17 & 155.42 & 170.15 \\
\hline 15 & 0.25 & 84.39 & 96.77 & 103.24 & 110.14 & 114.60 & 118.61 & 129.85 \\
\hline 20 & 0.33 & 69.66 & 79.88 & 85.22 & 90.92 & 94.60 & 97.91 & 107.18 \\
\hline 45 & 0.75 & 40.57 & 46.52 & 49.63 & 52.95 & 55.09 & 57.02 & 62.42 \\
\hline 60 & 1 & 33.49 & 38.40 & 40.97 & 43.71 & 45.48 & 47.07 & 51.53 \\
\hline 120 & 2 & 21.10 & 24.19 & 25.81 & 27.54 & 28.65 & 29.65 & 32.46 \\
\hline 180 & 3 & 16.10 & 18.46 & 19.70 & 21.01 & 21.86 & 22.63 & 24.77 \\
\hline 360 & 6 & 10.14 & 11.63 & 12.41 & 13.24 & 13.77 & 14.26 & 15.61 \\
\hline 720 & 12 & 6.39 & 7.33 & 7.82 & 8,34 & 8.68 & 8.98 & 9.83 \\
\hline 1080 & 18 & 4.88 & 5.59 & 5.97 & 6.62 & 6.62 & 6.85 & 7.50 \\
\hline 1440 & 24 & 4.03 & 4.62 & 4.92 & 5.47 & 5.47 & 5.66 & 6.19 \\
\hline
\end{tabular}

Sumber: Sriyono 2012.

kebetulan memiliki jenis tanah sama dengan yang ada pada lokasi penelitian.

Dari hasil pembagian antara debit puncak dan kapasitas peresapan biopori akan didapatkan hasil berupa jumlah biopori yang diperlukan untuk meresapkan air sebesar debit puncak tersebut dan jarak antar biopori. Namun demikian, adalah tidak mungkin untuk meresapkan seluruh air yang ada, mengingat jenis tanah di kawasan penelitian merupakan jenis tanah latosol.

Tanah jenis ini memiliki ciri kadar liat tanah lebih dari $60 \%$, memiliki struktur remah sampai gumpal, memiliki konsistensi gembur hingga agak teguh, memiliki warna coklat merah hingga kuning, memiliki profil tanah yang dalam (lebih dari $150 \mathrm{~cm}$ ). Jenis tanah ini telah berkembang atau mengalami diferensiasi horizon dan berasal dari batuan induk jenis tuf, material vulkanik dan breksi batuan beku intrusi. Jenis tanah ini berkategori agak kecil sehingga kurang mendukung kapasitas infiltrasi (Hardjowigeno, 2007).

Hasil penelitian lain dari jenis tanah pasir berlanau menunjukkan bahwa pada kondisi hujan lebat, biopori akan berhenti meresapkan air setelah 30 menit (Arviana et al, 2014). Hal ini turut menjadi pertimbangan dalam perhitungan, dimana

Infiltrasi oleh biopori hanya dihitung selama 30 menit saja. Selisih debit dan penurunan koefisien aliran permukaan sebelum dan sesudah simulasi aplikasi biopori disajikan pada Tabel 6 dan 7 .

\subsection{Pembahasan hasil simulasi}

Pepohonan dan vegetasi lain tidak hanya menyediakan mekanisme untuk mengurangi air larian permukaan melalui intersepsi, namun juga mampu mengurangi polutan dari air hujan melalui bioretensi dan filtrasi. Intersepsi air hujan pada tajuk pohon mencegah air hujan dari langsung menghantam tanah, sehingga mengurangi risiko erosi. Area di bawah tajuk pohon juga umumnya lebih mudah untuk meresapkan air ke dalam tanah karena adanya tambahan bahan organik dari pelapukan seresah dan juga karena adanya sistem perakaran dari pohon itu sendiri.

Hal ini dikonfirmasikan oleh Zadeh dan Sepaskhah (2016) yang menemukan 
Tabel 6. Perhitungan jumlah biopori yang dibutuhkan pada tiap periode ulang dan perubahan debit puncak serta koefisien air larian setelah simulasi aplikasi biopori.

\begin{tabular}{|c|c|c|c|c|c|c|c|c|c|c|}
\hline $\begin{array}{l}\text { Kelas } \\
\text { Tutupan } \\
\text { Lahan }\end{array}$ & $\begin{array}{l}\text { Periode } \\
\text { Ulang } \\
\text { (Tahun) }\end{array}$ & $\mathrm{C}_{\text {awal }}$ & $\begin{array}{c}\mathrm{I}(\mathrm{mm} / \\
\text { jam) }\end{array}$ & $A(\mathrm{Ha})$ & $\begin{array}{c}Q_{\mathrm{p}} \\
\left(\mathbf{m}^{3 /}\right. \\
\text { detik) }\end{array}$ & $\begin{array}{c}\text { Peresapan } \\
\text { Biopori } \\
\text { ( } \mathrm{m}^{3} / \text { detik) }\end{array}$ & $\begin{array}{c}\text { Jumlah } \\
\text { Biopori } \\
\text { yang } \\
\text { dibutuhkan }\end{array}$ & $\begin{array}{c}\text { Jarak } \\
\text { antar } \\
\text { Biopori }\end{array}$ & $\begin{array}{c}\mathbf{Q}_{\text {akhir }} \\
\left(\mathrm{m}^{3 /} /\right. \\
\text { detik })\end{array}$ & $\mathrm{C}_{\mathrm{akhir}}$ \\
\hline \multirow{7}{*}{ Pohon } & 2 & \multirow{7}{*}{0.50} & 21.10 & \multirow{7}{*}{184.11} & 5.40 & \multirow{7}{*}{0.000036} & 151.039 & 12.2 & 4.05 & \multirow{7}{*}{0.38} \\
\hline & 5 & & 24.19 & & 6.19 & & 173.158 & 10.6 & 4.64 & \\
\hline & 10 & & 25.81 & & 6.60 & & 185.755 & 10.0 & 4.95 & \\
\hline & 25 & & 27.54 & & 7.05 & & 197.139 & 9.3 & 5.29 & \\
\hline & 50 & & 28.65 & & 7.33 & & 205.084 & 9.0 & 5.50 & \\
\hline & 100 & & 29.65 & & 7.59 & & 212.242 & 8.7 & 5.69 & \\
\hline & 1000 & & 32.46 & & 8.31 & & 232.357 & 7.9 & 6.23 & \\
\hline \multirow{7}{*}{ Rumput } & 2 & \multirow{7}{*}{0.35} & 21.10 & \multirow{7}{*}{203.81} & 4.18 & \multirow{7}{*}{0.000036} & 117.040 & 17.4 & 3.14 & \multirow{7}{*}{0.27} \\
\hline & 5 & & 24.19 & & 4.80 & & 134.180 & 15.2 & 3.60 & \\
\hline & 10 & & 25.81 & & 5.12 & & 143.166 & 14.2 & 3.84 & \\
\hline & 25 & & 27.54 & & 5.46 & & 152.762 & 13.3 & 4.10 & \\
\hline & 50 & & 28.65 & & 5.68 & & 158.919 & 12.8 & 4.26 & \\
\hline & 100 & & 29.65 & & 5.88 & & 164.466 & 12.4 & 4.41 & \\
\hline & 1000 & & 32.46 & & 6.44 & & 180.053 & 11.3 & 4.83 & \\
\hline \multirow{7}{*}{$\begin{array}{l}\text { Tanah } \\
\text { Kosong }\end{array}$} & 2 & \multirow{7}{*}{0.52} & 21.10 & \multirow{7}{*}{55.31} & 1.69 & \multirow{7}{*}{0.000036} & 47.189 & 11.7 & 1.27 & \multirow{7}{*}{0.39} \\
\hline & 5 & & 24.19 & & 1.93 & & 54.100 & 10.2 & 1.45 & \\
\hline & 10 & & 25.81 & & 2.05 & & 57.723 & 9.6 & 1.55 & \\
\hline & 25 & & 27.54 & & 2.20 & & 61.592 & 9.0 & 1.65 & \\
\hline & 50 & & 28.65 & & 2.29 & & 64.074 & 8.6 & 1.72 & \\
\hline & 100 & & 29.65 & & 2.37 & & 66.310 & 8.3 & 1.78 & \\
\hline & 1000 & & 32.46 & & 2.60 & & 71.595 & 7.6 & 1.95 & \\
\hline
\end{tabular}

Tabel 7. Perhitungan koefisien air larian gabungan sebelum dan sesudah simulasi aplikasi biopori.

\begin{tabular}{|c|c|c|c|c|c|}
\hline \multirow{2}{*}{ Kelas Tutupan } & \multicolumn{2}{|c|}{ Estimasi Tutupan Lahan } & \multirow{2}{*}{$\begin{array}{l}\text { Koef. Air } \\
\text { Larian } \\
\text { (C) }\end{array}$} & \multicolumn{2}{|c|}{$\begin{array}{l}\text { Koef. Air Larian Gabungan (Luas } \\
\text { x C) }\end{array}$} \\
\hline & $(\%)$ & (Ha) & & $\begin{array}{l}\text { Sebelum } \\
\text { Biopori }\end{array}$ & Setelah Biopori \\
\hline \multicolumn{6}{|l|}{ Terbangun } \\
\hline Atap Bangunan & $23.30 \pm 1.34$ & $176.53 \pm 10.13$ & 0.95 & 167.70 & 167.70 \\
\hline Perkerasan/ Jalan & $11.40 \pm 1.01$ & $86.37 \pm 7.61$ & 0.95 & 82.05 & 82.05 \\
\hline \multicolumn{6}{|l|}{ Alami } \\
\hline Pohon & $24.30 \pm 1.36$ & $184.11 \pm 10.28$ & 0.50 & 92.05 & 69.04 \\
\hline Rumput/ Tumbuhan Bawah & $26.90 \pm 1.40$ & $203.81 \pm 10.62$ & 0.35 & 71.33 & 53.50 \\
\hline Air/ Kolam/ Sawah & $6.80 \pm 0.80$ & $51.52 \pm 6.03$ & 0.20 & 10.30 & 10.30 \\
\hline Terbuka & $7.30 \pm 0.82$ & $55.31 \pm 6.23$ & 0.52 & 28.76 & 21.57 \\
\hline Total & 100.00 & 757.64 & & 452.20 & 404.17 \\
\hline Koefisien air larian gabungan & & & & 0.60 & 0.53 \\
\hline
\end{tabular}


bahwa kondisi di bawah naungan pepohonan meningkatkan infiltrasi sebesar $69 \%$ pada tanah geluh pasiran dan sebesar $354 \%$ pada geluh lempung, bila dibandingkan dengan infiltrasi pada ruang di antara pepohonan. Pohon besar, terutama dari jenis evergreen, memiliki peran paling penting dalam intersepsi air hujan.

Permasalahan utama yang dihadapi kawasan perkotaan adalah kondisi tanah yang rawan mengalami pemadatan. Suatu area bisa saja ditutupi oleh naungan tajuk yang cukup ekstensif, misalnya pada taman kota, namun intensitas aktivitas manusia yang tinggi dapat mengakibatkan pemadatan tanah yang lebih lanjut berpengaruh terhadap infiltrasi seperti disajikan pada Tabel 8 berikut.

Tabel 8. Pengaruh Pemadatan Tanah Terhadap Laju Infiltrasi Tanah.

\begin{tabular}{cll}
\hline $\begin{array}{c}\text { Tekstur } \\
\text { Tanah }\end{array}$ & Kondisi & \multicolumn{1}{c}{$\begin{array}{c}\text { Rerata } \\
\text { Laju } \\
\text { Infiltrasi } \\
\text { (mm/ } \\
\text { Jam) }\end{array}$} \\
\hline Berpasir & Tidak Mengalami Pemadatan & 414 \\
& Mengalami Pemadatan & 64 \\
Lempung & Tidak Mengalami Pemadatan & 220 \\
& Mengalami Pemadatan & 20 \\
\hline
\end{tabular}

Sumber: Pitt et al (1999).

Bahkan tidak berlebihan jika dikatakan bahwa laju infiltrasi yang rendah di kawasan perkotaan bisa jadi merupakan akibat dari pemadatan tanah yang tinggi (Zadeh dan Sepaskhah, 2016). Hal ini diperparah oleh hilangnya serasah dan dedaunan akibat disapu dari bawah pohon yang mengakibatkan kurangnya kemampuan infiltrasi akibat kurangnya unsur organik dari permukaan tanah.

Untuk mengatasi hal ini, lubang resapan biopori diperkenalkan untuk mengatasi hal tersebut. Menurut Arviana et al (2014), aplikasi biopori mampu mengurangi volume limpasan sebesar 4 sampai $5 \%$ pada intensitas hujan deras merata. Pengurangan volume limpasan ini dapat ditingkat dengan menambah jumlah biopori per satuan unit lahan. Penutupan tanah terbuka dengan menggunakan rumput atau tanaman penutup tanah permanen juga mampu menurunkan aliran permukaan sebesar $80 \%$ (SMEC, 1998 dalam Suripin, 2012).

Tabel 9. Perhitungan Debit Rancangan Sebelum dan Sesudah Simulasi Aplikasi Biopori.

\begin{tabular}{ccccc}
\hline $\begin{array}{c}\text { Periode } \\
\text { Ulang } \\
\text { Tahun }\end{array}$ & $\mathbf{P}$ & $\begin{array}{c}\mathbf{1} \mathrm{mm} / \\
\text { jam }\end{array}$ & $\begin{array}{c}\text { Sebelum } \\
\text { Biopori }\end{array}$ & $\begin{array}{c}\text { Sesudah } \\
\text { Biopori }\end{array}$ \\
\hline 2 & 0.5 & 21.10 & 26.66 & 23.55 \\
5 & 0.2 & 24.19 & 30.57 & 27.00 \\
10 & 0.1 & 25.81 & 32.62 & 28.81 \\
25 & 0.04 & 27.54 & 34.80 & 30.74 \\
50 & 0.02 & 28.65 & 36.21 & 31.98 \\
100 & 0.01 & 29.65 & 37.47 & 33.10 \\
1000 & 0.001 & 32.46 & 41.02 & 36.24 \\
\hline
\end{tabular}

Bahkan tidak berlebihan jika dikatakan bahwa laju infiltrasi yang rendah di kawasan perkotaan bisa jadi merupakan akibat dari pemadatan tanah yang tinggi (Zadeh dan Sepaskhah, 2016). Hal ini diperparah oleh hilangnya serasah dan dedaunan akibat disapu dari bawah pohon yang mengakibatkan kurangnya kemampuan infiltrasi akibat kurangnya unsur organik dari permukaan tanah.

Untuk mengatasi hal ini, lubang resapan biopori diperkenalkan untuk mengatasi hal tersebut. Menurut Arviana et al (2014), aplikasi biopori mampu mengurangi volume limpasan sebesar 4 sampai $5 \%$ pada intensitas hujan deras merata. Pengurangan volume limpasan ini dapat ditingkat dengan menambah jumlah biopori per satuan unit lahan. Penutupan tanah terbuka dengan menggunakan rumput atau tanaman penutup tanah permanen juga mampu menurunkan aliran permukaan sebesar $80 \%$ (SMEC, 1998 dalam Suripin, 2012).

Dari hasil perhitungan pada Tabel 7, lebih lanjut bisa dihitung debit rancangan pada periode ulang tertentu dan pada kondisi sebelum dan sesudah aplikasi biopori. Hasil perhitungan ini menunjukkan bahwa aplikasi 
sejumlah biopori sesuai pada tabel 6 hanya mampu menurunkan debit puncak sebesar $12 \%$ saja. Hal ini mengingat jenis tanah di lokasi penelitian yang didominasi lempung seperti halnya yang terjadi pada penelitian Arviana et al (2014).

Berdasarkan hasil tersebut, perlu adanya bentuk pendekatan bioteknologi lainnya untuk dapat diaplikasikan sebagai sarana untuk menurunkan air larian permukaan di kawasan penelitian. Hal ini mengingat kita tidak mungkin bergantung sepenuhnya kepada biopori sebagai bentuk mitigasi terhadap ancaman banjir.

\section{KESIMPULAN DAN SARAN}

Dari hasil penelitian ini bisa disimpulkan bahwa persentase kondisi terbangun pada kawasan penyangga Situ Bojongsari terbilang cukup kecil dengan estimasi persentase tutupan sebesar $34.70 \pm 1.51 \%$ dari luas kawasan penelitian. Persentase kondisi alami pada kawasan penyangga Situ Bojongsari terbilang cukup baik dengan estimasi persentase tutupan sebesar $65.30 \pm 1.51 \%$ dari luas kawasan penelitian.

Simulasi aplikasi biopori pada tiga kelas tutupan lahan terpilih diperkirakan mampu mengurangi besaran koefisien air larian gabungan dari 0,60 menjadi 0,53 Diperkirakan hal ini mampu menurunkan debit puncak sebesar $12 \%$.

Penelitian lanjutan pada kawasan yang sama dapat difokuskan pada aplikasi bioteknologi lain untuk meningkatkan infiltrasi lebih tinggi lagi.

\section{UCAPAN TERIMA KASIH}

Penelitian ini merupakan bagian dari kegiatan DIPA Pusat Teknologi Reduksi Risiko Bencana Tahun Anggaran 2016. Penulis berterima kasih kepada Dr. Dwi Abad Tiwi, MUP, Dr. Odilia Rovara MS, , Deliyanti Ganesha, S.Si dan Novian Andri Akhirianto, S.P. atas bimbingan, bantuan dan kerjasamanya selama proses penelitian.

\section{DAFTAR PUSTAKA}

Arviana, I. D., S. Qomariyah, dan Sobriyah, 2014, Pengaruh Biopori terhadap infiltrasi dan limpasan pada tanah pasir berlanau, e-Jurnal Matriks Teknik, 461.

Hardjowigeno, 2007, IImu Tanah. Jakarta, Penerbit Pusaka Utama.

Henny, C dan A. A. Meutia, 2014, Urban Lakes in Megacity Jakarta: Risk and Management Plan for Future Sustainability. The 4th International Conference on Sustainable Future for Human Security, Sustain 2013. Procedia Environmental Sciences, 20 (2014): 737-746.

Juliastuti dan A. Suhendra, 2011, Studi Kapasitas Infiltrasi Metode Horton untuk Pemakaian Biopori di Kampus Universitas Bina Nusantara Berdasarkan Debit Limpasan Permukaan. Comtech, 2 (2): 1343-1349.

Pitt, R., Lantrip, J., Harrison, R., Henry, CH.L., Xue, D., dan O' Connor, T., 1999, Infiltration through disturbed urban soils and compostamended soil effects on runoff quality and quantity, Research Report of United States Environmental Protection Agency and Office of Researchand Development Washington DC 20460.

Sriyono, E, 2012, Analisis Debit Banjir Rancangan Rehabilitasi Situ Sidomukti, Jurnal Teknik, 2(2):78-87.

Suripin, 2002, Pelestarian Sumber Daya Tanah dan Air, Yogyakarta: Penerbit Andi, Hal. 144.

Suripin, 2003, Sistem Drainase Perkotaan yang Berkelanjutan, Yogyakarta, Penerbit Andi.

Zadeh, M. K. dan A. R. Sepaskhah, 2016, Effect of tree roots on water infiltration rate into the soil, Iran Agricultural Research, 35(1): 13-20. 